$h^{2}=\frac{\sigma_{a}^{2}}{\sigma_{a}^{2}+\sigma_{c}^{2}+\sigma_{e}^{2}}=$ narrow sense individual heritabil-

$c^{2}=\sigma_{c}^{2} /\left(\sigma_{a}^{2}+\sigma_{c}^{2}+\sigma_{e}^{2}\right)=$ correlation due to the common environmental effect in the plot;

$\sigma_{a}^{2}=$ additive genetic variance;

$\sigma_{c}^{2}=$ variance among plots;

$\sigma_{e}^{2}=$ residual variance (environmental within plot + non additive);

$\mathrm{A}=$ additive genetic correlation matrix among individuals under evaluation.

REML estimators for variance components using the EM (Expectation-Maximization) algorithm were:

$$
\begin{aligned}
& \hat{\sigma}_{e}^{2}=\left[y^{\prime} y-\hat{f}^{\prime} b^{\prime} y-\hat{a}^{\prime} Z^{\prime} y-\hat{c}^{\prime} W^{\prime} y\right] /[N-r(x)] \\
& \hat{\sigma}_{a}^{2}=\left[\hat{a}^{\prime} A^{-1} \hat{a}+\hat{\sigma}_{e}^{2} \operatorname{tr} A^{-1} C^{22}\right) / q
\end{aligned}
$$

$\hat{\sigma}_{c}^{2}=\left[\hat{c}^{\prime} c+\hat{\sigma}_{e}^{2} \operatorname{tr} C^{33}\right) / s$, where:

$\operatorname{tr}=$ trace operator;

$\mathrm{r}(\mathrm{x})=$ rank of the matrix $\mathrm{X}$;

$\mathrm{N}-\mathrm{r}(\mathrm{x})=$ error degrees of freedom;

$q$ = number of individuals;

$\mathrm{s}=$ number of plots;

$\mathrm{N}=$ Total number of data.

C22 and C33 come from:

$$
C=\left[\begin{array}{lll}
C^{11} & C^{12} & C^{13} \\
C^{21} & C^{22} & C^{23} \\
C^{31} & C^{32} & C^{33}
\end{array}\right]=\begin{aligned}
& \text { generalised inverse of the } \\
& \text { coefficient matrix of the } \\
& \text { mixed model equations. }
\end{aligned}
$$

The same model, excluding the plot effect, was applied to BSO data sets. For the interaction analyses involving the progeny and BSO data sets the family $\mathrm{x}$ trial interaction effect was added.

\title{
Variation in Eucalyptus globulus LABILL. and E. nitens DEAN and MAIDEN in Susceptibility of Adult Foliage to Disease Caused by Mycosphaerella cryptica (COOKE) HANSF.
}

\author{
By A. J. CARNEGIE ${ }^{1)}$ and P. K. Ades \\ Institute of Land and Food Resources, University of Melbourne, Parkville 3010, Victoria, Australia.
}

(Received $14^{\text {th }}$ February 2005)

\begin{abstract}
Summary
Severity of disease caused by Mycosphaerella cryptica (COOK) HANsF. was assessed on the adult foliage of Eucalyptus globulus LABILL. in two provenance trials (encompassing all four subspecies) and a progeny trial of $E$. globulus ssp. globulus LABILL. located in Victoria, Australia. Disease was relatively low in all trials (most trees with less than $15 \%$ crown severity), except for two provenances at one trial, Judbury (E. globulus ssp. globulus) and Mansfield (E. globulus ssp. bicostata), that had mean crown severities of approximately $25 \%$ and $40 \%$, respectively. Eucalyptus globulus ssp. bicostata (MAIDEN et al.) KIRKPATR. was significantly $(\mathrm{P}<0.01)$ more susceptible than $E$. globulus ssp. globulus, E. globulus ssp. pseudoglobulus (NAUDIN ex MAIDEN) KIRKPATR. and E. globulus ssp. maidenii (F. MuELl.) KIRKPATR., with subspecies maidenii significantly less diseased than all other subspecies. There was significant varia-

\footnotetext{
1) Corresponding author's current address: Forest Resources Research, NSW Department of Primary Industries, PO Box
} 100, Beecroft 2119, NSW, Australia; angusc@sf.nsw.gov.au.
\end{abstract}

tion between provenances within subspecies globulus $(\mathrm{P}<0.01)$ but not within subspecies pseudoglobulus, maidenii or bicostata. Subspecies globulus also showed significant $(\mathrm{P}<0.01)$ variation between families. There was a moderate to high genetic correlation between disease of the adult foliage and disease of the juvenile foliage (caused by both $M$. cryptica and $M$. nubilosa (COOKE) HANsf.) assessed several years earlier, both at the provenance $\left(\mathrm{r}_{\mathrm{G}}=0.67\right)$ and family $\left(\mathrm{r}_{\mathrm{G}}=0.33\right)$ levels. Narrow sense heritability of disease of the adult foliage (M. cryptica) was low $\left(\mathrm{h}^{2}=0.17\right)$, compared to that of the juvenile foliage $\left(\mathrm{h}^{2}=0.35\right)$ and juvenile defoliation $\left(\mathrm{h}^{2}=\right.$ $0.45)$ assessed previously. Selection for overall disease resistance (both adult- and juvenile-phase foliage) can be carried out more quickly and accurately at the juvenile stage when trees are 2-3 years old, potentially reducing the time required for resistant trees to be selected and deployed in the field. Mycosphaerella leaf disease on adult $E$. nitens (DEAN and MAIDEN) MAIDEN was also assessed in two provenance trials; however, there was very little disease observed and no significant differences were found between provenances. 
Key words: provenances, families, Mycosphaerella nubilosa, adult-juvenile leaf phase correlations, genetic parameters.

\section{Introduction}

Eucalyptus globulus LABILL., which is endemic to south-eastern Australia, is planted extensively throughout the temperate regions of the world and is the focus of intensive breeding programs (eg. VOLKER and ORME, 1988; Volker and RAYMOND, 1989; BorRALHO et al., 1992). Four subspecies of $E$. globulus have been described: E. globulus ssp. globulus LABILL., E. globulus ssp. pseudoglobulus (NAUDIN ex MAIDEN) KIRKPATR., $E$. globulus ssp. bicostata (MAIDEN et al.) KIRKPATR. and E. globulus ssp. maidenii (F. MUELL.) KIRKPATR. (KIRKPATRICK, 1974; JORDON et al., 1993). Of these, subspecies globulus is the most commonly planted in south-eastern and south-western Australia because of its generally superior growth rate and pulping qualities (VOLKER and RAYMOND, 1989; BorRAlHO et al., 1992). As a consequence of the increased economic importance of $E$. globulus the fungi that occur on it, and the damage they cause, have been studied more intensively in recent years.

Leaf diseases caused by species of Mycosphaerella JOHANSON have become a serious problem on $E$. globulus in Australia (PARK and KEANE, 1982a, b; CARNEGIE et al., 1994; Dungey et al., 1997; Milgate et al., 2001; MAXWell et al., 2003; CARNEGIE and AdES, 2003), New Zealand (Hood et al., 2002) and Chile (AHumADA et al., 2003). Mycosphaerella species also cause significant damage to $E$. nitens (DEAN and MAIDEN) MAIDEN in Australia (DUNGEY et al., 1997; CARNEGIE et al., 1998), New Zealand (HooD et al., 2002) and South Africa (LUNDQUIST and Purnell, 1987; Crous and WingField, 1996; HUNTER et al., 2004).

Both E. globulus and E. nitens are markedly heterophyllous (WILLIAMS and BROOKER, 1989), with distinct differences in juvenile- and adult-phase foliage. Juvenile foliage of $E$. globulus is susceptible to both $M$. nubilosa (CoOKe) Hansf. and M. cryptica (COOKE) HANsf. (PARK and KeANE, 1982a; Crous et al., 1995), with M. nubilosa commonly causing the most damage (CARNEGIE et al., 1994; Milgate et al., 2001; MAXWELl et al., 2003). This highly susceptible juvenile foliage phase lasts only for 23 years and is replaced by intermediate then adult foliage, which is highly resistant to $M$. nubilosa but still susceptible to M. cryptica (PARK and KEANE, 1982a, b; Crous et al., 1995; CARNEGIE and ADES, 2002). Mycosphaerella nubilosa has been isolated from adult foliage of $E$. globulus only in recent years, and only very rarely (MAXWELL et al., 2003; BARBER, 2005; KULARATNE et al., 2004). Juvenile foliage of $E$. nitens is susceptible to $M$. cryptica and not $M$. nubilosa in Australia (MARKS et al., 1982; PARK and KEANE, 1982b; CARNEGIE et al., 1998; CARnegie and Ades, 2002), but in South Africa it is susceptible to M. nubilosa (HunTER et al., 2004). The reasons for these conflicting results have not yet been resolved. Mycosphaerella cryptica has not been recorded from South Africa (CROUS and WINGFIELD, 1996; HUNTER et al., 2004). Adult foliage of $E$. nitens remains susceptible to $M$. cryptica but not $M$. nubilosa in Australia (Crous et al., 1995; CARnegie and AdEs, 2002). Thus
$M$. cryptica can cause problems throughout the life of the plantation and, while usually causing less dramatic symptoms, may ultimately cause the larger loss in growth.

Mycosphaerella leaf disease (caused by both pathogens, either singly or together) can cause premature defoliation of affected trees (up to $90 \%$ in severe cases) and has been known to markedly affect the growth and form of young, susceptible trees (DICK, 1982; LUNDQUist and PURNELl, 1987; CARNEGIE et al., 1994; CARNEGIE and AdEs, 2003).

Wide variation in susceptibility to Mycosphaerella leaf disease has been reported between Eucalyptus species (CARNEGIE et al., 1998; HoOD et al., 2002), provenances (WilcoX, 1982a; PURNELl and LUNDQUist, 1986; CARNEGIE et al., 1994, 1998; Dungey et al., 1997; HoOD et al., 2002) and families (WILCOX, 1982b; REINOso, 1992; Stefanatos, 1993; Dungey et al., 1997; Barber and KEANE, 2001; CARNEGIE et al., 2004). Most research has focused on young eucalypt plantations where trees are still in their juvenile-phase foliage, as this is when the disease is most dramatic and is relatively easy to assess. Standard disease assessment diagrams for severity and defoliation have been developed for use in 2-3-year-old stands (Lundquist and PuRnell, 1987; CARnegie et al., 1994) and these have been used widely (e.g., REINOso, 1992; Stefanatos, 1993; Dungey et al., 1997). However, as both $E$. globulus and $E$. nitens remain susceptible to $M$. cryptica throughout the rotation it is important to understand variation in susceptibility at later ages. If susceptibility in the adult phase is substantially genetically correlated with that in the juvenile phase then practical breeding for resistance would be a great deal easier than it could otherwise have been as indirect selection for adult resistance could be carried out successfully at the juvenile stage.

This paper describes how the field assessment technique has been successfully extended to disease caused by $M$. cryptica on adult foliage on older trees to assess two $E$. globulus provenance trials and one $E$. globulus progeny trial. One of the provenance trials and the progeny trial were previously assessed during the juvenile growth phase for severity of Mycosphaerella leaf disease, jointly caused by $M$. nubilosa and $M$. cryptica (Reinoso, 1992; Carnegie et al., 1994). Two E. nitens provenance trials were also assessed for disease caused by $M$. cryptica on the juvenile and adult foliage.

\section{Materials and Methods}

\section{Description of trials}

Silver creek: Established by Grand Ridge Plantations in June 1986 at Silver Creek, Victoria, Australia (36 23' $\left.\mathrm{S}, 146^{\circ} 44^{\prime} \mathrm{E}\right)$. It consists of 28 provenances of $E$. globulus, encompassing all four subspecies (Table 1), and four provenances of $E$. nitens (Table 2). The experimental design for the trial was a randomised complete block with single-tree plots and 40 replicates, with trees planted at a square spacing of $3 \mathrm{~m}$.

Tostaree: A eucalypt species and provenance trial established in October 1988 by the Department of Sus- 
tainability and Environment, Victoria, near Nowa Nowa in Victoria, Australia ( $\left.37^{\circ} 47^{\prime} \mathrm{S}, 148^{\circ} 11^{\prime} \mathrm{E}\right)$. The experimental design was a randomised complete block with 25 -tree square plots and 5 replicates. Trees were spaced $3 \mathrm{~m} \times 3 \mathrm{~m}$ on a square grid. Nine provenances of $E$. globulus (encompassing all four subspecies) (Table 3) and six provenances of $E$. nitens (Table 2) were assessed. This trial was previously assessed for severity of Mycosphaerella leaf disease in the juvenile growth phase in 1991 (CARNEGIE et al., 1994, 1998).

Mount Worth: This E. globulus ssp. globulus progeny trial was established in June 1989 near Mount Worth State Park, Victoria, Australia ( $\left.38^{\circ} 16^{\prime} \mathrm{S}, 145^{\circ} 59^{\prime} \mathrm{E}\right)$ by Grand Ridge Plantations. It compares 52 open pollinated families collected from wild trees growing in the vicinity of Apollo Bay, Victoria ( $38^{\circ} 46^{\prime} \mathrm{S}, 143^{\circ} 40^{\prime} \mathrm{E}$ ). The experimental design for the trial was a randomised complete block with single-tree plots and 20 replicates. Trees were spaced $3.6 \mathrm{~m} \times 2.8 \mathrm{~m}$ on a rectangular grid. This trial was previously assessed for severity of Mycosphaerella leaf disease in the juvenile growth phase in 1992 (REINOSO, 1992).

\section{Assessment of Mycosphaerella leaf disease on the adult foliage}

Mycosphaerella cryptica on adult foliage was associated with irregular lesions, often $10 \mathrm{~mm}$ wide by $20 \mathrm{~mm}$ long with callused margins and distorting the leaf, similar to those described by CARNEGIE and ADES (2002). Due to the size of trees (many over $15 \mathrm{~m}$ tall), an ordinal disease assessment scale was developed for subjectively assessing severity of $M$. cryptica in the whole crown: 0 (no infection), 1 (<1\% leaf area affected), 2 ( 1 to $<15 \%)$ and $3(>15 \%)$. This scale was used for assessing the Silver Creek trial but for subsequent assessment of the Tostaree and Mount Worth trials, a finer scale with more categories was used: $0,1(<1 \%), 2$ ( 1 to $<15 \%), 3$ $(15 \%$ to $<30 \%), 4(30 \%$ to $<45 \%)$ and $5(>45 \%)$. This was developed to account for higher disease in trees at Tostaree, especially in provenances of subspecies bicostata. The whole crown of each tree was assessed for severity of $M$. cryptica, with the aid of binoculars, by an observer walking along the rows.

At Silver Creek, each tree in 20 replicates was assessed for $M$. cryptica on adult foliage in December 1992 and again in March 1993. At Tostaree, the nine internal trees from each plot of $E$. globulus and $E$. nitens in the five replicates were assessed in March 1993. Each tree in 10 replicates was assessed at Mount Worth in early April 1994.

\section{Statistical analyses}

Analyses of variance were carried out for the severity scores for all sites to test for variation in susceptibility of adult foliage to disease, and for both assessments of $M$. cryptica at Silver Creek to test for provenance by time interaction. Genetic and phenotypic correlations were estimated between disease severity in juvenile and adult foliage for families at Mount Worth, and phenotypic and "genetic" correlations for provenances at Tostaree. All analyses were carried out using the GLM procedure of SAS (SAS, 1996). At Silver Creek there were no significant differences in disease scores between the original 21 Jeeralang provenances. All were collected from different trees along a forest road, so they were combined as one provenance (Jeeralang) for analysis.

\section{Genetic parameters}

SQUILLACE (1974) suggested that in real situations the coefficient of relationship between putative half-sibs from open-pollinated seedlots will usually be appreciably larger than that which is commonly used (1/4) and that this will cause an overestimate of genetic variance and therefore of heritability. MORAN and BELL (1983) estimated outcrossing rates for a wide range of Eucalyptus species and determined an average rate of outcrossing of $70 \%$. In this study, narrow-sense individual tree heritability $\left(\mathrm{h}^{2}\right)$, additive genetic variance and covariance were estimated assuming an average outcrossing rate of $70 \%$ resulting in a coefficient of relationship among the sibs of $1 /{ }_{2.5}$. This value has been used by various authors to estimate genetic parameters from openpollinated families of E. globulus (e.g., VoLKER et al., 1990; Reinoso, 1992; Dungey et al., 1997) and E. nitens (Dungey et al., 1997).

Under this assumption, additive genetic variance was estimated as 2.5 times the family variance and narrow sense heritability was calculated as:

$$
\mathrm{h}^{2}=2.5 \hat{\mathrm{o}}_{\mathrm{f}}^{2} /\left(\hat{\mathrm{o}}_{\mathrm{e}}^{2}+\hat{\mathrm{o}}_{\mathrm{f}}^{2}+\hat{\mathrm{o}}_{\mathrm{r}}^{2}\right)
$$

where $\hat{o}_{\mathrm{e}}^{2}, \hat{\mathrm{o}}_{\mathrm{f}}^{2}$ and $\hat{\mathrm{o}}_{\mathrm{r}}^{2}$ represent respectively the residual, family and replicate variance components.

Least square estimates of variance and covariance components were obtained by equating expected and actual mean squares and products. Additive genetic correlations between traits were calculated by using additive genetic variances and covariances as indicated by HAZEL et al. (1943). These genetic parameters were calculated for families at Mount Worth.

A "genetic correlation" between traits (disease in the juvenile foliage and disease in the adult foliage) were calculated for provenance means at Tostaree using the formula:

$$
\mathrm{r}_{\mathrm{G}}=\operatorname{Cov}_{1,2} / \hat{\mathrm{o}}_{1} \hat{\mathrm{o}}_{2}
$$

where $\mathrm{Cov}_{1,2}$ is the provenance covariance component of traits 1 (disease in the juvenile foliage) and 2 (disease in the adult foliage), $\hat{o}_{1}$ and $\hat{o}_{2}$ are the square roots of the provenance variance components.

\section{Results}

\section{Silver Creek}

Overall, disease in this trial was low, with most trees having a score of 0 or 1 (i.e. less than $1 \%$ crown severity). Many trees in subspecies bicostata had higher scores (many trees with a score of 2 and rarely 3 ), but still with provenance averages of less than $15 \%$ crown severity (mean scores less than 2). There were significant $(\mathrm{P}<0.01)$ differences in disease severity on adult foliage between the four E. globulus subspecies at Silver 
Table 1. - Subspecies, origin and disease severity caused by M. cryptica on the adult foliage (mean of 2 assessments ${ }^{1}$ ) of the E. globulus provenances at Silver Creek.

\begin{tabular}{|c|c|c|c|c|c|}
\hline \multirow{2}{*}{$\begin{array}{l}\text { E. globulus } \\
\text { subspecies }\end{array}$} & \multicolumn{4}{|c|}{ Origin } & \multirow{2}{*}{$\begin{array}{l}\text { Mean }^{1} \\
\text { disease } \\
\text { severity } \\
\text { (score) }\end{array}$} \\
\hline & Provenance & $\begin{array}{c}\text { Latitude } \\
\text { o "S }\end{array}$ & $\begin{array}{c}\text { Longitude } \\
\text { o "E }\end{array}$ & $\begin{array}{c}\text { Elevation } \\
m\end{array}$ & \\
\hline bicostata & Mount Cole, Vic ${ }^{2}$ & 3717 & 14317 & 700 & 1.69 \\
\hline bicostata & Toombullup, Vic & 3653 & 14600 & 840 & 1.20 \\
\hline bicostata & Strathbogie, Vic & 3651 & 14544 & 870 & 1.93 \\
\hline globulus & Macquarie Harbour, Tas & 4224 & 14514 & 20 & 0.02 \\
\hline globulus & Henty River, Tas & 4201 & 14517 & 50 & 0.08 \\
\hline globulus & Leprena, Tas & 4331 & 14655 & 20 & 0.16 \\
\hline globulus & Bruny Island, Tas & 4323 & 14719 & 180 & 0.14 \\
\hline globulus & Channel, Tas & 4315 & 14711 & 100 & 0.16 \\
\hline globulus & Geeveston, Tas & 4312 & 14658 & 200 & 0.17 \\
\hline globulus & Denison, Tas & 4259 & 14650 & 240 & 0.32 \\
\hline globulus & Uxbridge, Tas & 4247 & 14650 & 500 & 0.81 \\
\hline globulus & Jericho, Tas & 4225 & 14745 & 500 & 0.21 \\
\hline globulus & Pepper Hill, Tas & 4136 & 14747 & 560 & 0.30 \\
\hline globulus & Taranna, Tas & 4302 & 14753 & 120 & 0.22 \\
\hline globulus & Swansea, Tas & 4208 & 14802 & 100 & 0.12 \\
\hline globulus & Rheban, Tas & 4240 & 14753 & 80 & 0.09 \\
\hline globulus & Seymour, Tas & 4113 & 14817 & 20 & 0.07 \\
\hline globulus & Scamander, Tas & 4127 & 14813 & 50 & 0.05 \\
\hline globulus & St. Helens, Tas & 4112 & 14815 & 50 & 0.18 \\
\hline globulus & North Flinders Island, Tas & 3947 & 14755 & 50 & 0 \\
\hline globulus & South Flinders Island, Tas & 4013 & 14802 & 50 & 0.01 \\
\hline globulus & Otways, Vic & 3840 & 14344 & 44 & 0 \\
\hline globulus & Portugal & - & - & - & 0.18 \\
\hline maidenii & Tantawanglo, NSW & 3646 & 14938 & 380 & 0 \\
\hline maidenii & Mount Dromedary, NSW & 3636 & 15004 & 305 & 0.03 \\
\hline maidenii & Nerrigundah, NSW & 3607 & 14954 & 245 & 0 \\
\hline pseudoglobulus & Jeeralang, Vic $^{3}$ & 3834 & 14615 & 400 & 0.05 \\
\hline pseudoglobulus & Kuark, Vic & 3735 & 14846 & - & 0.18 \\
\hline \multicolumn{5}{|c|}{ Least Significant Difference $(\mathrm{P}<0.01)$} & 0.22 \\
\hline
\end{tabular}

Creek (Tables 1 and 4) with subspecies bicostata being significantly more susceptible than subspecies globulus, pseudoglobulus and maidenii, and subspecies maidenii significantly less susceptible than the other three. Subspecies bicostata had the highest mean severity in December (1.72) and March (1.50), and these values were significantly higher than all other subspecies. Subspecies globulus was the next most severely affected with a mean of 0.14 in December and 0.20 in March while subspecies pseudoglobulus had a mean severity of 0.06 in December and 0.19 in March. Subspecies maidenii had very low severity scores, with only one tree having any trace of the disease (score of 1 ) in the trial in either year.

Disease severity differed significantly between the 20 provenances within subspecies globulus $(\mathrm{P}<0.01)$, but variation in disease severity within subspecies pseudoglobulus, bicostata or maidenii was not significant (Tables 1 and 5). Provenances of subspecies bicosta$t a$ were the most severely affected with mean scores ranging from 1.20 (Toombullup) to 1.93 (Strathbogie). Uxbridge had the highest mean disease score within subspecies globulus with 0.81 , which was higher than for any provenance other than the three in subspecies bicostata. Denison was the next most severely affected, and the fifth overall, with a score of 0.32 , while Pepper Hill had a severity score of 0.30 . No disease was recorded in either year on a few provenances of subspecies globulus (viz. North Flinders Island and Otways). Severity scores for the remaining subspecies globulus provenances ranged from 0.01 to 0.22 .

In general, disease severity increased for each provenance from December 1992 to March 1993 at Silver Creek (data not shown) and there was a high phenotypic correlation $(\mathrm{r}=0.47, \mathrm{P}<0.01)$ between provenance means for the two assessment dates. Mean severity for subspecies globulus and subspecies pseudoglobulus increased from 0.14 to 0.20 and 0.06 to 0.19 , respectively, in the three months from December 1992 to March 1993. In both subspecies, severity for some provenances increased markedly in the three months between assessments. Portugal (subspecies globulus) increased from 0.06 to 0.31 , while for some of the Jeeralang families (subspecies pseudoglobulus) the average score increased 
three-fold. Disease was observed for subspecies maidenii only at the March 1993 assessment, there being no disease seen in these trees in December 1992. For subspecies bicostata there was a decrease in mean disease severity from 1992 (1.72) to 1993 (1.50). Severity on Mount Cole and Strathbogie decreased from 1.84 and 2.14 to 1.53 and 1.71, respectively, between December 1992 and March 1993, and hence brought down the average for this subspecies. Premature shedding of leaves severely affected in December 1992 may account for the reduction in observed disease severity in March 1993. 'Shot-hole' damage (holes in leaves due to biotic agents such as insects or fungi) to the leaves of these and other trees was observed during the 1993 assessment but it could not be determined for certain whether this was damage caused by $M$. cryptica or by herbivorous insects. This may also account for the reduction.

Severity of $M$. cryptica on adult $E$. nitens foliage at Silver Creek was very low, with few trees having any disease and these only in one provenance (Table 2). There were no significant differences between provenances so correlations with disease of juvenile foliage were not calculated.

Table 2. - E. nitens provenances assessed at Silver Creek (SC) and Tostaree (T): origin and severity of $M$. cryptica (score) on the adult foliage in March 1993.

\begin{tabular}{lccc}
\hline \multicolumn{1}{c}{ Origin } & & & \\
\hline & $\begin{array}{c}\text { Latitude } \\
\text { o "S }\end{array}$ & $\begin{array}{c}\text { Longitude } \\
\text { o "E }\end{array}$ & $\begin{array}{c}\text { Adult } \\
\text { Severity }\end{array}$ \\
\hline Snobs Creek, Vic (SC) & 3716 & 14553 & 0 \\
Snobs Creek, Vic (SC) & 3716 & 14553 & 0 \\
Mount St. Gwinear, Vic (SC) & - & - & 0 \\
Loch Valley, Vic (SC) & 3748 & 14601 & 0.08 \\
Mt. Erica, Vic (T) & 3753 & 14621 & 0.06 \\
Mt. Kaye, Vic (T) & 3724 & 14915 & 0.17 \\
Powelltown, Vic (T) & 3752 & 14545 & 0.17 \\
Snobs Creek, Vic (T) & 3716 & 14553 & 0.06 \\
Tallaganda, NSW (T) & 3539 & 14939 & 0.11 \\
Tooronga Plateau, Vic (T) & 3750 & 14606 & 0.06 \\
\hline
\end{tabular}

\section{Tostaree}

Disease severity was higher at Tostaree than either Silver Creek or Mount Worth. Most trees scored 0, 1 or 2 ; with most provenance means below 2 (i.e. crown severity of less than $15 \%$ ). However, two provenances had higher means: Judbury (subspecies globulus) had a mean score of 2.89, which equates to approximately $25 \%$ crown severity, and Mansfield (subspecies bicostata) had a mean score of 4.49 , which equates to a crown severity of approximately $40 \%$.

There were highly significant $(\mathrm{P}<0.01)$ differences in disease severity for adult foliage between the $E$. globulus subspecies and provenances assessed at Tostaree in March 1993 (Table 3). The Mansfield provenance, subspecies bicostata, had the highest adult disease score with 4.49 and Judbury, subspecies globulus, was the next most severely affected provenance with a mean of 2.89. Eden, subspecies maidenii, and Wye River, subspecies globulus, had the lowest severities for adult foliage with 0.56 and 0.50 , respectively. There was wide variation within subspecies globulus which ranged from 0.50 (Wye River) through to 1.38 (Otway National Park) and up to 2.89 (Judbury). Note that Wye River and Otway National Park are located in close geographical proximity to one another in the Otway region in western Victoria but have almost a three-fold difference in disease severity.

There was a moderately high phenotypic correlation of the provenance means $(\mathrm{r}=0.53, \mathrm{P}<0.01)$ between severity of $M$. cryptica on the adult foliage and disease severity on the juvenile foliage at Tostaree (juvenile foliage data from CARNEGIE et al., 1994). The "genetic correlation" between disease on the juvenile foliage phase with that in the adult foliage phase was moderately high $\left(\mathrm{r}_{\mathrm{G}}=0.69\right)$. In both leaf phases Judbury (subspecies globulus) and Mansfield (subspecies bicostata) had the highest disease severity scores while Eden (subspecies maidenii) and Kuark (subspecies pseudoglobulus) had amongst the lowest. The ranking of the provenances didn't change greatly between assessments of juvenile and adult foliage, except for Wye River (subspecies globulus), which had moderate severity in 1991 (juvenile leaf phase) but had the lowest severity when assessed in the adult phase (1993).

Table 3. - Subspecies, origin and disease severity of M. cryptica on adult foliage and severity of Mycosphaerella leaf disease on juvenile foliage ${ }^{1}$ of $E$. globulus provenances at Tostaree (untransformed scores).

\begin{tabular}{|c|c|c|c|c|c|c|}
\hline \multirow{2}{*}{$\begin{array}{l}\text { E. globulus } \\
\text { subspecies }\end{array}$} & \multirow[b]{2}{*}{ Provenance } & \multicolumn{2}{|c|}{ Origin } & \multirow[b]{2}{*}{$\begin{array}{c}\text { Elevation } \\
\mathrm{m}\end{array}$} & \multicolumn{2}{|c|}{ Disease severity } \\
\hline & & $\begin{array}{c}\text { Latitude } \\
\text { o "S }\end{array}$ & $\begin{array}{c}\text { Longitude } \\
\text { o "E }\end{array}$ & & Adult & Juvenile! \\
\hline bicostata & Mansfield, Vic & 3703 & 14605 & 160 & 4.49 & 23.1 \\
\hline globulus & Judbury, Tas & 4259 & 14655 & 100 & 2.89 & 26.9 \\
\hline globulus & King Is., Tas & 3846 & 14332 & 200 & 0.96 & 19.9 \\
\hline globulus & Otway Nat. Pk, Vic & 3655 & 14930 & - & 1.38 & 21.6 \\
\hline globulus & St. Helens, Tas & 3834 & 14615 & 400 & 1.33 & 18.7 \\
\hline globulus & Wye River, Vic & 3735 & 14846 & - & 0.50 & 14.8 \\
\hline maidenii & Eden, NSW & 3652 & 14611 & 780 & 0.58 & 4.2 \\
\hline pseudoglobulus & Jeeralang, Vic & 3823 & 14627 & - & 1.47 & 17.5 \\
\hline pseudoglobulus & Kuark, Vic & 4112 & 14815 & 50 & 0.78 & 9.8 \\
\hline \multicolumn{2}{|c|}{ Least Significant Difference $(\mathrm{P}<0.01)$} & & & & 0.37 & - \\
\hline
\end{tabular}

${ }^{1}$ From CARNEGIE et al. (1994) 
Table 4. - Analysis of variance of mean severity score (rank transformed ${ }^{1}$ ) on adult-phase foliage for subspecies of E. globulus at Silver Creek.

\begin{tabular}{lcccc}
\hline Source of variation & df & Mean square & F & Prob \\
\hline Replications & 19 & 0.262 & 7.26 & 0.0001 \\
Year & 1 & 0.001 & 0.004 & 0.950 \\
Subspecies & 3 & 23.800 & 101.624 & $<0.01$ \\
Year*Subspecies & 3 & 0.234 & 5.74 & 0.0017 \\
Error & 57 & 0.041 & & \\
\hline
\end{tabular}

${ }^{1}$ The rank-transformation procedure was carried out on the Silver Creek data and gave the same conclusion as the parametric ANOVA employed, so according to ZAR (1996, p 267-271), this conclusion is dependable.

Table 5. - Analyses of variance for provenance means (rank transformed ${ }^{1}$ ) within E. globulus subspecies at Silver Creek.

\begin{tabular}{|c|c|c|c|c|c|c|c|c|c|c|c|c|c|c|c|c|}
\hline \multirow{2}{*}{$\begin{array}{l}\text { Subspecies } \\
\text { Source of } \\
\text { variation }\end{array}$} & \multicolumn{4}{|c|}{ bicostata } & \multicolumn{4}{|c|}{ globulus } & \multicolumn{4}{|c|}{ maidenii } & \multicolumn{4}{|c|}{ pseudoglobulus } \\
\hline & df & $\begin{array}{l}\text { Mean } \\
\text { square }\end{array}$ & $\mathrm{F}$ & Prob & $\mathrm{df}$ & $\begin{array}{l}\text { Mean } \\
\text { square }\end{array}$ & F & Prob & $\mathrm{df}$ & $\begin{array}{l}\text { Mean } \\
\text { square }\end{array}$ & F & Prob & $\mathrm{df}$ & $\begin{array}{l}\text { Mean } \\
\text { square }\end{array}$ & $\mathrm{F}$ & Prob \\
\hline Replications & 19 & 238.51 & 1.36 & 0.225 & 19 & 7573.61 & 2.36 & 0.001 & 19 & 9.63 & 0.70 & 0.783 & 19 & 138.84 & 2.26 & 0.05 \\
\hline Provenance & 2 & 58.32 & 0.33 & 0.719 & 19 & 10015.14 & 3.11 & 0.001 & 2 & 13.49 & 0.98 & 0.388 & 1 & 343.06 & 5.60 & 0.31 \\
\hline Error & 27 & 174.78 & & & 286 & 3215.47 & & & 26 & 13.73 & & & 16 & 61.31 & & \\
\hline
\end{tabular}

${ }^{1}$ The rank-transformation procedure was carried out on the Silver Creek data and gave the same conclusion as the parametric ANOVA employed, so according to ZAR (1996, p 267-271), this conclusion is dependable.

Table 6. - Analysis of variance for family means of disease caused by $M$. cryptica on the adult foliage at Mount Worth.

\begin{tabular}{lcccc}
\hline Source of variation & df & Mean square & F & Prob \\
\hline Replications & 19 & 1.677 & 2.29 & 0.001 \\
Family & 36 & 1.634 & 2.24 & 0.001 \\
Error & 476 & 0.731 & & \\
\hline
\end{tabular}

Again very low levels of disease were observed on the adult foliage of the $E$. nitens at Tostaree, with only one to three trees in each provenance with any observable disease, and this only a score of 1 (Table 2). Consequently, there were no significant differences between provenances, and no correlations with juvenile foliage were calculated.

\section{Mount Worth}

Disease was low in this trial, with most trees scoring 0,1 , or 2 , and mean severity of $M$. cryptica (scores) ranging from 0.30 to 2.02 (i.e. mean crown severity of less than $15 \%$ ) (data not shown). Wide variation in severity of $M$. cryptica in the adult foliage was observed between the E. globulus ssp. globulus families at Mount Worth (Table 6) and differences between families were highly significant $(\mathrm{P}<0.01)$. Data of REINOSO (1992) of severity of Mycosphaerella leaf disease and defoliation of the juvenile foliage at Mount Worth was re-analysed, with some coding errors corrected and runts removed, and revealed significant $(\mathrm{P}<0.01)$ variation between families. There was no significant phenotypic correlation in disease severity between the two phases (Table 7). However, there was a significant negative phenotypic correlation $(\mathrm{r}=-0.12, \mathrm{P}<0.01)$ between severity of $M$. crypti$c a$ on the adult foliage and defoliation caused by Mycosphaerella leaf disease in the juvenile growth phase and a low but significant positive phenotypic cor- relation $(\mathrm{r}=0.17, \mathrm{P}<0.01)$ between disease severity on the juvenile foliage and defoliation of the juvenile crown (Table 7).

Estimated heritabilities and genetic correlations $\left(\mathrm{r}_{\mathrm{G}}\right)$ of all traits assessed at Mount Worth are given in Table 7. Narrow sense heritability for adult disease was low (0.17) compared to the higher heritabilities of juvenile severity (0.35) and defoliation (0.45). There was a moderate positive genetic correlation between $M$. cryptica on the adult foliage and juvenile severity (0.33). In con-

Table 7. - Estimates of genetic correlations $\left(\mathrm{r}_{\mathrm{G}}\right)$ (above the diagonal), phenotypic correlations (below the diagonal), and individual heritability $\left(\mathrm{h}^{2}\right)$ (in bold) for damage traits on juvenile foliage ${ }^{1}$ and adult foliage at Mount Worth.

\begin{tabular}{lccc}
\hline \multicolumn{1}{c}{ Trait } & $\begin{array}{c}\text { M. cryptica } \\
\text { on adult } \\
\text { foliage }\end{array}$ & $\begin{array}{c}\text { Mycosphaerella } \\
\text { leaf disease on } \\
\text { juvenile foliage }\end{array}$ & $\begin{array}{c}\text { Defoliation of } \\
\text { juvenile crown }\end{array}$ \\
\hline $\begin{array}{l}\text { M. cryptica } \text { on } \\
\text { adult foliage }\end{array}$ & $\mathbf{0 . 1 7}$ & 0.33 & -0.46 \\
$\begin{array}{l}\text { Mycosphaerella } \\
\text { leaf disease on } \\
\text { juvenile foliage }\end{array}$ & ns & $\mathbf{0 . 3 5}$ & 0.20 \\
$\begin{array}{l}\text { Defoliation of } \\
\text { juvenile crown }\end{array}$ & -0.12 & 0.17 & $\mathbf{0 . 4 5}$ \\
\end{tabular}

${ }^{1}$ From Reinoso (1992). 
trast, there was a negative genetic correlation between $M$. cryptica on the adult foliage and defoliation of the juvenile crown $(-0.46)$.

\section{Discussion}

Disease severity in the three trials was relatively low, with most trees having a score of less than 2, which equates to a crown severity of less than $15 \%$. Disease severity overall was higher at Tostaree, with two provenances in this trial having significantly higher damage: Judbury (subspecies globulus) with a mean score of 2.89 (equates to approximately $25 \%$ crown severity) and Mansfield (subspecies bicostata) with a mean score of 4.49 (equates to approximately $40 \%$ crown severity). This indicates that disease caused by $M$. cryptica in adult foliage, at least in most provenances, is not a significant health threat to older trees.

The disease assessment scale devised here for fieldbased assessments proved effective in establishing the relative susceptibility of the various $E$. globulus subspecies, provenances and families to damage on adult foliage caused by $M$. cryptica. Other rating scales developed for assessing leaf diseases of Eucalyptus have also proved useful (e.g., for Mycosphaerella leaf disease on juvenile foliage (Lundquist and PURNELL, 1987; CARNEGIE et al., 1994); for target spot caused by Aulographina eucalypti (COOKE and MASSEE) ARX and Müller (CARNEgIE and KeAne, 2003); and for Phaeophleospora epicoccoides (COOKE and MASSEE) Crous et al. (= Phaeseptoria eucalypti) (NICHOL et al., 1992). Whereas the above authors assessed a single branch chosen at random, the method of assessment in this study was of the whole (adult) crown, a method which has proven to be more effective in assessing Mycosphaerella leaf disease on juvenile foliage of E. globulus (Reinoso, 1992; Stefanatos, 1993; Dungey et al., 1997; CARNEGIE and ADES, 2003) and E. pilularis SMith (CARNEGIE et al., 2004) and adult foliage of E. globulus (CARNEGIE and ADES, 2001). A method that also assesses the whole crown for damage, the Crown Damage Index (CDI), has recently been developed as a standard for assessment of insect and fungal damage to young eucalypt trees (STONE et al., 2003a, b).

There are, however, possible weaknesses in using our scoring and analysis methods. Since the scale is not linear, differences between classes of damage (e.g., between class 0 and class 1 , and between class 2 and class 3) are not of the same magnitude. This problem could have been avoided by measuring every tree according to its percentage of infection or by adopting a mid-point value for analysis. Assessing the percentage of infection (such as the CDI, STONE et al., 2003b) was not possible as we were assessing crowns of trees that were mostly over $15 \mathrm{~m}$ tall. Our primary aim of this study was to rank the provenances for their susceptibility of $M$. cryptica, which our analysis did sufficiently. However, using a mid-point for analysis would have shown the magnitude of differences more clearly.

Wide variation in susceptibility of the adult foliage to $M$. cryptica was observed between the E. globulus subspecies at both provenance trials, with provenances of subspecies bicostata significantly more susceptible than provenances within subspecies globulus, pseudoglobulus and maidenii. Provenances from subspecies bicostata have previously been observed as having the most severely diseased juvenile foliage in other trials (CARNEGIE et al., 1994; Hood et al., 2002). However, an unknown provenance of subspecies bicostata was the least damaged in a trial in north-west Tasmania (DUNGEY et al., 1997) with both the adult and juvenile foliage being moderately resistant to Mycosphaerella spp. This suggests that there is more variation in subspecies bicostata than has previously been reported, and this subspecies should not be discounted for commercial plantations based on disease alone, as has previously been suggested (CARNEGIE et al., 1994).

There was very little damage by $M$. cryptica on the three provenances from subspecies maidenii at Silver Creek, with provenances from this subspecies consistently less diseased than the majority of provenances from subspecies globulus, pseudoglobulus and bicostata, an observation that has been made previously (CARNEGIE et al., 1994; Hood et al., 2002). This subspecies is not grown commercially in plantations in Australia. However, this work suggests that it may well need to be re-considered, assuming growth and pulping characteristics are suitable, if $E$. globulus is to be grown successfully in areas where Mycosphaerella species cause severe damage and growth loss. In a trial in northern New South Wales, Australia, subspecies maidenii is outperforming the widely planted $E$. dunnii MAIDEN, E. grandis Hill ex MAIDEN, Corymbia citriodora ssp. variegata (F. MUELL.) MCDONALD and BEAN and $E$. grandis hybrids in terms of growth and pest and disease resistance at five years of age (CARNEGIE and JOHNson, unpublished data).

There were no significant differences in disease severity of adult foliage amongst provenances within subspecies bicostata and maidenii at Silver Creek. However, there were only three provenances of each subspecies, and a more extensive trial, with more provenances, may reveal more variation within these subspecies. The need to include sufficient numbers of genotypes when making comparisons has been noted previously (Dungey et al., 1997). There was little difference in disease severity between the two provenances from subspecies pseudoglobulus planted at Silver Creek (Kuark and Jeeralang), but a significant difference between the same provenances (although they were different seedlots) planted at Tostaree, with Jeeralang being moderately diseased and Kuark significantly less so. This suggests that there is wide variation within pseudoglobulus from Jeeralang, even though this was not observed in the provenances studied at Silver Creek. At both sites, the Kuark seedlots had among the lowest disease scores of all $E$. globulus provenances. Disease at Tostaree was more severe overall than that observed at Silver Creek, and this may have affected the relative susceptibility of the two provenances at the two sites, as has been observed for other forest diseases (WHITE and HodGe, 1989).

Provenances within subspecies globulus consistently showed wide variation in susceptibility of adult foliage 
to $M$. cryptica in this study. At Silver Creek, Uxbridge was the fourth most diseased provenance, after the three subspecies bicostata provenances. Denison and Pepper Hill also had high levels of disease at Silver Creek while, in contrast, Macquarie Harbour, Scamander, North and South Flinders Island and Otways had no or very little disease. Subspecies globulus provenance Judbury was the second most severely diseased at Tostaree, and Wye River recorded the least disease in that trial. Both these provenances were significantly more and less diseased, respectively, than all other subspecies globulus planted at Tostaree. The remaining provenances of subspecies globulus at both sites had low to moderate severity, with no significant variation between them.

Climatic conditions in the place of origin of the seed source have previously been identified to explain variation in Eucalyptus in disease susceptibility by species of Mycosphaerella (WILCOX, 1982a; LUNDQUIST and PURNELL, 1987; CARNEGIE et al., 1994, 1998; DUNGEY et al., 1997; CARNEGIE et al., 2004). Warm, wet weather (i.e. summer rain) is reported to increase the chances of successful infection by species of Mycosphaerella (CHEAH, 1977; PARK, 1988a). So species of Eucalyptus that originated from areas where these conditions predominate may have evolved under conditions with high populations of these leaf-infecting fungi, and hence, may have had more intense natural selection for resistance to Mycosphaerella spp. In contrast, trees from environments that were cooler or with dry summers would likely have had little previous exposure to Mycosphaerella, and thus are likely to be severely damaged when exposed to these pathogens.

Similar observations have been reported for diseases in other tree genera (eg. ZHANG et al., 1996; YANG et al., 1997) and were also made in the current study. The majority of the provenances with severe disease at Tostaree and Silver Creek are from areas where summer rainfall and/or mean temperatures are low (e.g., Mount Cole, Toombulup and Strathbogie from subspecies bicostata, and Uxbridge, Judbury, Denison and Pepper Hill from subspecies globulus). In contrast, provenances that had no or very little disease were from areas where summer rainfall and/or mean maximum temperatures were relatively high (eg. Macquarie Harbour and Otways from subspecies globulus, Jeeralang from subspecies pseudoglobulus, and the three subspecies maidenii provenances, Tantawanglo, Mount Dromedary and Nerrigundah). Preliminary analysis indicates that disease severity of provenances planted at Silver Creek is negatively correlated with mean maximum yearly temperature $(r=-0.35)$ and mean summer rainfall $(\mathrm{r}=-0.28)$ in their original location (CARNEGIE, unpublished data). In contrast, HooD et al. (2002) reported no effect of climatic conditions in the place of origin to explain variation in Eucalyptus in disease susceptibility by species of Mycosphaerella. More studies are needed to fully understand whether climatic conditions have led to evolution of this variation in susceptibility to Mycosphaerella leaf disease amongst these provenances.

Detailed studies of morphological variation in $E$. globulus have been conducted to investigate geographic pat- terns of genetic variation (JORDAN et al., 1994; DuTKOwsKI and POTTS, 1999). This work resulted in the identification of races within $E$. globulus spp. globulus based on variation in growth and morphological traits and geographic distribution. These "races" may also help to explain the variation in Mycosphaerella damage in the E. globulus provenances and subspecies globulus families studied here.

There is also considerable variation within subspecies globulus in the persistence of the juvenile foliage, with trees from localities in the Strzelecki Ranges in Victoria, and the north-eastern and south-eastern coastal areas of Tasmania producing juvenile foliage for longer than trees from other localities (DUTKOWSKI and PoTTS, 1999). Since both $M$. nubilosa and $M$. cryptica infect juvenile foliage of $E$. globulus, it is likely that trees with more juvenile foliage will experience relatively more damage from these fungi than trees with less juvenile foliage. Assessments of a 3-year-old E. globulus provenance trial in Gippsland, Victoria, support this hypothesis. Damage to juvenile foliage was more severe on Judbury (southeast coast, Tasmania) and moderate on St Helens (north-east coast, Tasmania) and Jeeralang (Strezlecki Ranges) when compared to provenances from other regions in Victoria and Tasmania that had lower disease (CARNEGIE et al., 1994). This trait could therefore be used to reduce the impact of Mycosphaerella leaf disease by reducing the length of time trees are exposed to the more damaging $M$. nubilosa. However, both susceptibility of the juvenile phase and persistence of the juvenile foliage can vary in $E$. globulus. Juvenile foliage of the Jeeralang provenance is less susceptible to Mycosphaerella leaf disease than that of other provenances but there is a longer juvenile foliage phase (REINOso, 1992).

The narrow sense heritability for severity of $M$. crypti$c a$ on the adult foliage at Mount Worth was low (0.17) compared to that for juvenile severity $(0.35)$ at the same trial. This could be due to the low severity of adult disease and the coarseness of the field scoring technique. A finer and more linear scale (eg. increments of $5 \%$ like that for juvenile foliage score) would be superior for heritability and genetic gain estimation but was impractical in the field where the observer must visually assess crowns of trees over $15 \mathrm{~m}$ tall. Assessment using a finer scale may have differentiated susceptibility of the families more precisely, and thus have resulted in higher estimates of heritability and genetic correlations. Expression of genetic variation in disease resistance may also be dependent on the level of infection (WHITE and HodGe, 1989) and, since the level of infection in adult foliage at the Mount Worth trial was relatively low, these differences may not have been as detectable using the broad assessment scale.

The heritability for adult disease at Mount Worth was lower than those reported by DUNGEY et al. (1997), which ranged from 0.19 to 0.34 . DunGEY et al. (1997) assessed younger trees that were in the transition from juvenile to adult foliage, thus assessments of adult foliage would have been easier and possibly more accurate as the trees were smaller. Disease was higher in 
the study by DungeY et al. (1997) compared to Mount Worth, and the lower infection at Mount Worth may have adversely affected calculations of heritability (see White and HodGe, 1989). Also, there was intermediate foliage present on trees assessed by DUNGEY et al. (1997), which were included as "adult", whereas there was no intermediate foliage on the trees assessed in the current study. The intermediate foliage included in the assessment by DUNGEY et al. (1997) may be more susceptible than the truly adult foliage on older trees at Mount Worth, and the reduction in susceptibility of leaf phases may be progressive - from juvenile to intermediate to adult - thus affecting the result.

The moderate positive genetic correlation between severity of disease on the adult foliage (M. cryptica) and severity of disease on the juvenile foliage ( $M$. cryptica and $M$. nubilosa) (0.33) suggest that indirect selection may be useful in breeding programs. Again, the scale used makes these estimates less reliable, although the main point is that they are positive. Selection for resistance to Mycosphaerella leaf disease of the juvenile foliage can be easily carried out on small trees at age 2-3 years. Therefore, selection can be made at this age and an increase in adult resistance should be achieved indirectly. This bodes well for breeding for resistance, as selection for overall disease resistance (both adult- and juvenile-phase foliage) can be carried out more quickly and accurately at the juvenile stage, potentially reducing the time required for resistant trees to be selected and deployed in the field.

Provenances from the Otway region of Victoria (subspecies globulus) are widely used in breeding programs in Australia. Otway National Park and Wye River were moderately affected by $M$. cryptica while Otways was highly resistant, despite the close geographical proximity of these provenances. CARNEGIE et al. (1994) reported significant variation in susceptibility of the juvenile foliage between provenances from this region. Similarly, provenances from Jeeralang (subspecies pseudoglobulus) are widely used in breeding programs in Australia and wide variation was observed within this provenance. Careful selection of provenances and families from these areas is necessary to achieve the greatest possible gains from plantations established in areas where there is a high risk of Mycosphaerella leaf disease.

The severity of Mycosphaerella leaf disease increased over time on the adult foliage of $E$. globulus at Silver Creek, confirming previous findings. LUNDQUIST and PURNELl (1987) reported that Mycosphaerella leaf disease symptoms on $E$. nitens in South Africa were well advanced by late summer. PARK (1988b) reported that severity of $M$. cryptica on $E$. globulus reached a peak during summer and that this followed high rainfall on consecutive days during warm weather. CARNEGIE et al. (1994) also observed that severity of Mycosphaerella leaf disease on juvenile foliage of $E$. globulus was highest in summer, following warm, wet conditions. Therefore, assessments of Mycosphaerella leaf disease should be carried out in summer when the disease is at it maximum "expression”.
At Mount Worth, we observed a negative genetic correlation between disease in adult foliage and defoliation of the juvenile crown, although disease in juvenile and adult foliage was positively correlated. REINOSO (1992) reported very low genetic and phenotypic correlations between juvenile severity and defoliation at Mount Worth, in contrast to the high $(r=0.99$, LUNDQUIST and Purnell, 1987) and moderate $(\mathrm{r}=0.53$, CARNEGIE et al., 1994) correlations between the same traits reported in other studies. This suggests that Mycosphaerella leaf disease was not causing defoliation at Mount Worth. This was discounted by REINOSO (1992), as defoliation was occurring very rapidly at the time of assessment, and leaves that were falling were heavily infected by $M$. cryptica and $M$. nubilosa with no other disease or possible cause evident. The trial was at a high quality site, also removing nutrition as a cause of premature leaf fall. The high genetic correlation between Mount Worth and its paired site (the lower site quality Tom's Cap) indicates the same factor was causing defoliation at both sites. By the same logic differential response to shading can be rejected. It could have occurred at Mount Worth where growth had been very rapid but at Tom's Cap stand growth and crown development were slow and none of the trees was significantly shaded.

Another possibility for the low correlation between juvenile disease and juvenile defoliation at Mount Worth is the consequence of severe infection beginning in the spring and increasing through the season so by the end of the summer most of the juvenile foliage had been lost (REINOSO, 1992; ADES, pers. obs.). Very few new juvenile leaves were produced on these branches subsequently. Defoliation at the time of assessment may have been more highly correlated with juvenile severity earlier in the season. Therefore, defoliation (or juvenile severity for that matter) may not have been assessed at the time for optimum "expression" of this trait. This may explain the negative correlation between defoliation and adult disease that we observed. Defoliation assessed by REINOSO (1992) was probably not a true reflection of the full extent of disease severity for these trees and, if it had been assessed later in the season when defoliation had "run its course", then we would have observed a more accurate reflection of this trait.

CARNEGIE et al. (2004) observed a negative correlation between target spot disease of juvenile $E$. pilularis leaves, caused by $A$. eucalypti, and defoliation of the whole crown, assessed at the same time. While contrary to what may be expected, they suggested that it was likely to be a result of $A$. eucalypti being slow growing, and mainly observed on older leaves in the lower and inner crown (WALL and KEANE, 1984). If these same leaves are also infected with Mycosphaerella spp. (which they were) they are more likely to be shed more quickly. Once this occurred then little A. eucalypti damage would be observed. CARNEGIE et al. (2004) assessed three traits - severity of target spot, Mycosphaerella leaf disease and defoliation - and suggested that there are optimum times in a season to assess these three different "disease" traits. The very high correlation between sites reported by REINOSO (1992) suggests that juvenile severity and defoliation are measures of different components 
of susceptibility. The low correlation between the two (REINOso, 1992) suggest that they also should be assessed at different times in the disease cycle.

Disease on adult foliage of $E$. nitens was very low in this trial, consistent with Mycosphaerella leaf disease not being a serious problem on adult foliage for this species. However, disease can be severe on juvenile foliage, causing significant defoliation (LUNDQUIST and Purnell, 1987; Dungey et al., 1997; CARNEGIE et al., 1998; Hood et al., 2002; HUNTER et al., 2004). Species of Mycosphaerella were associated with moderate to severe defoliation in mature $E$. denticulata CoOK and LADIGES (recently split from E. nitens) in Victoria in 1974, although $A$. eucalypti was identified as the main pathogen (NEUMANN and MARKs, 1976).

We recommend a multi-faceted approach to reducing the impact of Mycosphaerella leaf disease in E. globulus plantations that includes silviculture and genetics. Studies have shown that nutrient addition improves health of trees infected with Mycosphaerella spp. (CARNEGIE and ADES, 2001; WARDLAW, pers. comm.), which is likely to be related to tolerance (infected leaves are retained on healthy trees longer) and foliage replacement. Disease severity on juvenile foliage is moderately heritable, and correlated with severity on adult foliage, as is height to phase change. Breeding programs should concentrate on selecting trees with low juvenile disease severity, thus selecting indirectly for adult resistance, and include reduced time in juvenile foliage (assuming good growth and pulping qualities). This can be achieved when trees are 2-3 years old. Once planted, adequate fertiliser regimes should enable trees to tolerate Mycosphaerella infection during the juvenile phase and grow into the less susceptible adult foliage sooner, thus reducing the impact of Mycosphaerella leaf disease.

\section{Acknowledgments}

The authors thank PhiLlip KEANE, CAROLYN RAYMOND and NunO BORRALHO for reviewing a previous draft of the manuscript, CARLos Reinoso for the data from Mount Worth, and the Australian Research Council for funding. This work would have been impossible without the cooperation of Grand Ridge Plantations and the Victorian Department of Sustainability and Environment who provided access to their trials.

\section{References}

Ahumada, R., G. Hunter, B. D. Wingfield and M. J. WINGFIELD (2003): Molecular and morphological identification of Mycosphaerella spp. associated with Eucalyptus leaf disease in Chile. In: $8^{\text {th }}$ International Congress of Plant Pathology: Solving problems in the real world. Proceedings, 2-7 Feb. 2003, Christchurch, New Zealand.

BARBER, P. A. (2005): A taxonomic study of foliar diseases of eucalypts in plantations and native forests of southeastern Australia. Ph.D. Thesis, La Trobe University, Australia.

BARBer, P. A. and P. J. KeAne (2001): Foliar diseases of blue gum plantations and eucalypts in native forest of south-eastern Australia. In: $13^{\text {th }}$ Biennial Australasian Plant Pathology Conference Hand Book, Cairns, Australia, p. 151.
Borralho, N. M. G., P. P. Cotterill and P. J. KANOwski (1992): Genetic parameters and gains expected from selection for dry weight in Eucalyptus globulus ssp. globulus in Portugal. For. Sc. 38: 80-94.

CARnegie, A. J. and P. K. Ades (2001): Added phosphorus is associated with reduced severity of Mycosphaerella cryptica in Eucalyptus globulus. Aust. For. 64: 203-208.

CARnEGie, A. J. and P. K. AdES (2002): The proportion of leaf spots caused by Mycosphaerella cryptica and $M$. nubilosa on Eucalyptus globulus, E. nitens and their F1 hybrids in a family trial in Tasmania, Australia. Aust. Mycol. 2: 53-63.

CARnegie, A. J. and P. K. Ades (2003): Mycosphaerella leaf disease reduces growth of plantation-grown Eucalyptus globulus. Aust. For. 66: 113-119.

Carnegie, A. J., P. K. Ades, P. J. Keane and I. W. Smith (1998): Mycosphaerella diseases of juvenile foliage in a eucalypt species and provenance trial in Victoria, Australia. Aust. For. 61: 190-194.

CARnegie, A. J., I. G. Johnson and M. Henson (2004): Variation among provenances and families of blackbutt (Eucalyptus pilularis) in early growth and susceptibility to damage from leaf spot fungi. Can. J. For. Res. 34: 2314-2326.

CARnegie, A. J. and P. K. KeAne (2003): Variation in severity of target spot, caused by Aulographina eucalyp$t i$, in a eucalypt species and provenance trial in Victoria. Aust. Plant. Path. 32: 393-402.

Carnegie, A. J., P. J. Keane, P. K. Ades and I. W. Smith (1994): Provenance variation in Eucalyptus globulus in susceptibility to Mycosphaerella leaf disease. Can. J. For. Res. 24: 1751-1757.

CHEAH, L. H. (1977): Aerobiology and epidemiology of Mycosphaerella nubilosa (CKE) HANSF. on Eucalyptus spp. Master of Forest Science. University of Auckland, New Zealand.

Crous, P. W. and M. J. WingField (1996): Species of Mycosphaerella and their anamorphs associated with leaf blotch disease of Eucalyptus in South Africa. Mycologia 88: 441-458.

Crous, P. W., A. J. Carnegie and P. J. Keane (1995): IMI descriptions of fungi and bacteria, set 121. Mycosphaerella cryptica, M. delegatensis, M. gracilis, M. heimii, M. marksii, M. molleriana, M. parkii, M. suberosa, M. swartii, M. walkeri. Mycopath. 130: 43-64.

Dick, M. (1982): Leaf-inhabiting fungi of eucalypts in New Zealand. NZ J. For. Sci. 12: 525-537.

Dungey, H. S., B. M. Potts, A. J. CARnegie and P. K. Ades (1997): Mycosphaerella leaf diseases: Genetic variation in damage to Eucalyptus nitens, E. globulus and their F1 hybrid. Can. J. For. Sci. 27: 750-759.

Dutkowski, G. W., and B. M. PotTs (1999): Geographic patterns of genetic variation in Eucalyptus globulus ssp. globulus and a revised racial classification. Aust. J. Bot. 47: 237-263.

Hazel, L. N., M. L. BaKer and C. F. Reinmiller (1943): Genetic and environmental correlations between the growth rates of pigs at different ages. J. Animal Sci. 2: $118-128$.

Hood, I. A., J. F. GARdNer and M. O. KimberLey (2002): Variation among eucalypt species in early susceptibility to the leaf spot fungi Phaeophleospora eucalypti and Mycosphaerella spp. NZ J. For. Sci. 32: 235-255.

Hunter, G. C., P. W. Crous, J. Roux, B. D. Wingfield and M. J. WingFIELD (2004): Identification of Mycosphaerel- 
la spp. associated with leaf disease of Eucalyptus nitens in South Africa. Aust. Plant Path. 33: 349-355.

Jordan, G. J., N. M. G. Borralho, P. Tilyard and B. M. POTTS (1994): Identification of races in Eucalyptus globulus ssp. globulus based on growth traits in Tasmania and geographic distribution. Silvae Genet. 43: 292-298.

Jordan, G. J., B. M. PotTs, J. B. KiRKPATRICK and C. GARDINER (1993): Variation in the Eucalyptus globulus complex revisited. Aust. J. Bot. 41: 763-785.

KIRKPATRICK, J. B. (1974): The numerical intraspecific taxonomy of Eucalyptus globulus LABILL. (Myrtaceae). Bot. J. Linn. Soc. 69: 89-104.

Kularatne, H. A. G. C, A. C. Lawrie, P. A. Barber and P. J. KEANE (2004): A specific primer PCR and RFLP assay for the rapid detection and differentiation in planta of some Mycosphaerella species associated with foliar diseases of Eucalyptus globulus. Mycol. Res. 108: 1476-1493.

Lundquist, J. E. and R. C. PURNELL (1987): Effects of Mycosphaerella leaf spot on growth of Eucalyptus nitens. Plant Dis. 71: 1025-1029.

MARKS, G. C., B. A. Fuhrer and N. E. M. WAlters (1982): Tree diseases in Victoria. Forest Commission Victoria Handbook No. 1. Melbourne: Forests Commission, Victoria.

Maxwell, A., B. Dell, H. G. Neumeister-Kemp and HARDY, G. E. ST J. (2003): Mycosphaerella species associated with Eucalyptus in south-western Australia: new species, new records and a key. Mycol. Res. 107: 351-359.

Milgate, A. W., Z. Q. Yuan, R. E. Vaillancourt and C. MoHAMmed (2001): Mycosphaerella species occurring on Eucalyptus globulus and Eucalyptus nitens plantations of Tasmania, Australia. For. Path. 31: 53-63.

MorAn, G. F. and J. C. BELL (1983): Eucalyptus. In: Isozymes in plants, genetics and breeding, Part B. Elsevier, Amsterdam. pp. 423-441.

Neumann, F. G. and G. C. Marks (1976): A synopsis of important pests and diseases in Australian forests and forest nurseries. Aust. For. 39: 83-102.

Nichol, N. S., M. J. WingField and W. J. Swart (1992): Differences in susceptibility of Eucalyptus species to Phaeoseptoria eucalypti. Euro. J. For. Path. 22: 418-423.

PARK, R. F. (1988a): Effect of certain host, innoculum, and environmental factors on infection of Eucalyptus species by two Mycosphaerella species. Trans. Br. Mycol. Soc. 90: $221-228$.

PARK, R. F. (1988b): Epidemiology of Mycosphaerella nubilosa and $M$. cryptica on Eucalyptus species in south-eastern Victoria. Trans. Br. Mycol. Soc. 91: 261-266.

PARK, R. F. and P. J. KeAne (1982a): Three Mycosphaerella species from leaf diseases of Eucalyptus. Trans. Br. Mycol. Soc. 79: 95-100.

PARK, R. F. and P. J. KEANE (1982b): Leaf diseases of Eucalyptus associated with three Mycosphaerella species. Trans. Br. Mycol. Soc. 79: 101-115.

PotTs, B. M., and G. J. JoRDAN (1994): Genetic variation in the juvenile leaf morphology of Eucalyptus globulus LABILL. ssp globulus. For. Genet. 1: 81-95.
PuRnell, R. C. and J. E. LindQuist (1986): Provenance variation of Eucalyptus nitens on the Eastern Traansvaal Highveld in South Africa. S. Af. For. J. 138: 23-31.

Reinoso, C. (1992): Variation in Eucalyptus globulus in susceptibility to Mycosphaerella leaf diseases. Master of Forest Science. The University of Melbourne, Australia.

SAS (1996): SAS/STAT Software, Changes and Enhancements through Release 6.11. SAS Institute Inc.: Cary, NC.

Squillace, A. E. (1974): Average genetic correlations among offspring from open-pollinated forest trees. Silvae Genet. 23: 159-156.

Stefanatos, A. (1993): A study of the severity of leaf parasites on Eucalyptus globulus in a progeny trial and E. regnans in a silvicultural systems trial. B. Sc. Honours, La Trobe University, Australia.

Stone, C., T. WARdlaW, R. Floyd, A. J. CARnegie, R. Wylie and D. De LitTle (2003a): Harmonisation of Methodologies for the Assessment and Reporting of Forest Health in Australia - A Starting Point. Aust. For. 66: $233-246$.

Stone, C., M. Matsuki and A. J. Carnegie (2003b): Pest and disease assessment in young eucalypt plantations: field manual for using the Crown Damage Index, ed. PARSON, M. National Forest Inventory, Bureau of Rural Sciences, Canberra.

VOLKER, P. W. and R. K. ORME (1988): Provenance trials of Eucalyptus globulus and related species in Tasmania. Aust. For. 51: 257-265.

Volker, P. W. and C. A. RAYMOND (1989): Potential for breeding eucalypts in Tasmania. Appita 42: 198-199.

Volker, P. W., C. A. DeAn, W. N. TibBits and I. C. RAVENWOOD (1990): Genetic parameters and gains expected from selection in Eucalyptus globulus in Tasmania. Silvae Genet. 39: 18-21.

WALL, E. and P. J. KeANE (1984): Leaf spot of Eucalyptus caused by Aulographina eucalypti. Trans. Brit. Mycol. Soc. 82: 257-273.

WILCOX, M. D. (1982a): Preliminary selection of suitable provenances of Eucalyptus regnans for New Zealand. NZ J. For. Sci. 12: 468-479.

WILCOX, M. D. (1982b): Selection of genetically superior Eucalyptus regnans using family tests. NZ J. For. Sci. 12: 480-493.

Williams, K. S. and M. I. H. BrookeR (1989): Eucalypts: an introduction. Eucalypt ecology: Individuals to ecosystems (ed. By J. W. Williams and J. C. Z. WoinARSki), pp 1-15. Cambridge University Press, Melbourne.

White, T. L. and G. R. Hodge (1989): Predicting breeding values with applications in forest tree improvement. For. Sci. 33: 173-207.

YANG, R-C., N. K. Dhir, F. C. YEH and Y. HiRATsuka (1997): Geographic variation in susceptibility of Alberta lodgepole pine to western gall rust. Can. J. For. Res. 27: 1398-1405.

ZAR, J. H. (1996): Biostatistical analysis. Third Edition. Prentice-Hall International, Inc.

Zhang, J. W., N. B. Kloppenstein and G. W. Peterson (1996): Genetic variation in disease resistance of Juniperus virginiana and J. scopulorum grown in Eastern Nebraska. Silvae Genet. 46: 11-16. 